\title{
Factors associated with diet quality of older adults
}

\author{
Fatores associados à qualidade \\ da dieta de idosos
}

Tatiana Império de FREITAS ${ }^{1}$

Ágatha Nogueira PREVIDELLI²

Marcela Previato do Nascimento FERREIRA ${ }^{3}$

Karina Maffei MARQUES ${ }^{4}$

Rita Maria Monteiro GOULART4

Rita de Cássia de AQUINO ${ }^{4}$

\section{A B S T R A C T}

\section{Objective}

Evaluate the factors associated with diet quality of older adults from the city of São Caetano do Sul, São Paulo, Brazil.

\section{Methods}

A cross-sectional study was carried out on a sample of 295 older adults receiving care in health care units in São Caetano do Sul. Diet quality was assessed using the Brazilian Healthy Eating Index. The associations between the diet quality mean score and the socio-demographic, economic, and anthropometric characteristics and lifestyle and health conditions were verified using multiple linear regression.

\section{Results}

Lower diet quality mean score were associated with the variables: marital status (widowed or separated) $(\beta=-2.02 ; p=0.047)$, retired $(\beta=-4.24 ; p=0.034)$, and smoking $(\beta=-8.06 ; p=0.001)$; whereas higher diet quality mean score were associated with higher education level (9 years or more) $(\beta=3.49 ; p=0.013)$.

\section{Conclusion}

Individuals with higher education level had better diet quality, and those who were widowed or separated, retired, and smokers had worse diet quality indicating that socio-demographic, economic, and lifestyle are factors that can influence food choice of older adults.

Keywords: Aging. Elderly nutrition. Food consumption.

\footnotetext{
1 Universidade Cruzeiro do Sul, Curso de Nutrição. Av. Regente Feijó, 1295, Jd. Anália Franco, 03342-000, São Paulo, SP, Brasil. Correspondência para/Correspondnce to: TI FREITAS. E-mail: <tatiana-imerio@hotmail.com>.

2 Universidade São Judas Tadeu, Curso de Nutrição. São Paulo, SP, Brasil.

${ }^{3}$ Universidade Municipal de São Caetano do Sul, Curso de Nutrição. São Caetano do Sul, SP, Brasil.

${ }^{4}$ Universidade São Judas Tadeu, Programa de Pós-Graduação em Ciências do Envelhecimento. São Paulo, SP, Brasil.
} 


\section{R E S U M O}

\section{Objetivo}

Avaliar os fatores associados à qualidade da dieta de idosos de São Caetano do Sul, São Paulo.

\section{Métodos}

Estudo transversal em uma amostra de 295 idosos usuários das unidades de saúde do município de São Caetano do Sul. A qualidade alimentar foi avaliada pelo Índice de Qualidade da Dieta Revisado. As associações entre as médias do Índice de Qualidade da Dieta Revisado e variáveis sociodemográficas, econômicas, antropométricas, estilo de vida e condições de saúde foram verificadas por meio de regressão linear múltipla.

\section{Resultados}

Ao relacionar as variáveis com o Índice de Qualidade da Dieta Revisado, o estado civil viúvo ou separado ( $\beta=-2,02$; $p=0,047)$, estar aposentado $(\beta=-4,24 ; p=0,034)$ e o hábito de fumar $(\beta=-8,06 ; p=0,001)$ determinaram índices menores, enquanto que em idosos com maior escolaridade ( 9 anos ou mais de estudo) as médias observadas foram maiores $(\beta=3,49 ; p=0,013)$.

\section{Conclusão}

A qualidade da dieta apresentou-se melhor em individuos com maior escolaridade e pior em viúvos ou separados, aposentados e fumantes, indicando que fatores sociodemográficos, econômicos e de estilo de vida podem influenciar nas escolhas alimentares de idosos.

Palavras-chave: Envelhecimento. Nutrição do idoso. Consumo de alimentos.

\section{NTRODUCTION}

Population aging is progressing rapidly, especially in developing countries. Forecasts indicate that by 2025 Brazil will have the 6th largest elderly population, reaching approximately 35 million in absolute numbers [1]. In 2010, the elderly population in the municipality of São Caetano do Sul (SP) was 19.1\%, and in the last 10 years, the city has had the highest Municipal Human Development Index in the country [2].

There is a physiological decline in food intake with aging mainly due to loss of appetite, decreased gustatory and olfactory functions, swallowing disorders, and the adoption of a less varied diet [3], which can affect the nutritional value of the foods consumed. The Inquérito Nacional de Alimentação (National Dietary Survey) 2008-2009 assessed the dietary habits of older adults in Brazil, and the data showed high prevalence of inadequate intake of vitamins ( $A, C, D, E$, thiamine, and pyridoxine) and minerals (calcium, magnesium, zinc, and copper) [4]. Moreover, $91 \%$ of the Brazilian adult population consume inadequate amounts of macronutrients [5], which may increase the risk of chronic diseases.

The qualitative approach to dietary assessment, in terms of food and/or food groups, is used to investigate population dietary habits and the dietary factors associated with reduced risk of chronic diseases. Therefore, Previdelli et al. [6] proposed the revised Brazilian Healthy Eating Index (BHEI) for the Brazilian population based on recommendations for healthy eating. Due to the growth in the elderly population and the effects of food consumption on health, evaluating the quality of the diet has become essential for developing nutritional interventions to promote a healthy diet.

Some studies [5,7-13] have identified factors that can influence dietary choices and diet quality, especially socio-demographic, economic, anthropometric factors, as well as lifestyle, and health conditions. Taking into account the current scenario and the importance of determining and monitoring the diet quality of this age group, the objective of the present study was to evaluate the factors associated with diet quality of older adults in the municipality of São Caetano do Sul (SP). 


\section{METHODS}

A descriptive cross-sectional study was carried out on a non-probability sample of 295 older adults of both genders aged 60 years and older receiving care in health care units in São Caetano do Sul (SP) which were geographically distributed in the city's fifteen boroughs. Data were collected between February 2014 and February 2015.

Sample size was determined according to the method proposed by Hair et al. [14], which establishes that the minimum number of individuals should be five times the number of food items evaluated. A sample of 288 individuals was estimated to carry out multiple regression analysis with 95\% confidence interval, $5 \%$ sampling error, and $10 \%$ loss of participants.

The data were collected by nutritionists who were previously trained by a professor specialized in dietary intake assessment. Older adults receiving care in Basic Care Units or participating in Centros de Terceira Idade (Senior Centers) were invited to take part in the study by the researchers and were informed about the objectives and procedures of the study.

The participants answered a structured questionnaire consisting of socio-demographic and socio-economic questions: gender, age, marital status, household composition, education level (years of study), employment status, and per capita income (in minimum wages); anthropometric questions: nutritional status according to body mass index; lifestyle factors: physical activity (yes or no) and smoking habit; and health condition factors: dental health, chewing problems, choking or gagging when swallowing, abdominal pain, use of laxatives, and presence of Chronic Non-Communicable Diseases such as hypertension, dyslipidemia, and diabetes Mellitus. Marital status was separated into groups in the multiple regression analysis as follows: married and 'widowed or separated or divorced', which was considered a single variable denominated "widowed or separated".
In order to evaluate the nutritional status, weight and height were measured in an appropriate place using proper equipment and techniques. The measurements were used to calculate Body mass index according to the cut-off points recommended by the Pan American Health Organization [15].

Food consumption was evaluated using the methods recommended by the Grupo de Pesquisa de Avaliação do Consumo Alimentar (Food Consumption Evaluation Research Group) of the School of Public Health Universidade de São Paulo [16]. An adapted Food Frequency Questionnaire was administered and two 24-Hour Dietary Recall (24HR) interviews were conducted, with an interval of two weeks, to estimate habitual food consumption of a sub-sample of $30 \%$ of the participants. The interviews were evenly distributed over the days of the week and months of the year, considering the variability in food consumption patterns during the week and across seasons. The participants were instructed to keep a record of all foods eaten on the day before the interview to reduce the forgetfulness during the $24 \mathrm{HR}$ interviews.

Diet quality was evaluated using the revised BHEl developed by Previdelli et al. [6] comprising twelve components: nine are related to food groups (total fruit, whole fruit, total vegetables, dark green and orange vegetables, legumes, total grains, whole grains, milk and other dairy products, meat, eggs, and oils), two are related to nutrients (saturated fat and sodium), and one is related to the energetic value from solid fat (saturated and trans fat), alcohol, and added sugar (Chart 1). The components were scored as $0,5,10$, and 20 points; the method is described in detail in the study by Previdelli et al. [6].

After the field research, the data from the $24 \mathrm{HR}$ and the food frequency questionnaire were converted; the quantitative estimates of the $24 \mathrm{HR}$ data were performed by the conversion of preparations or food intake data recorded in household measures into grams and 
Chart 1. Distribution of the components of the Brazilian Healthy Eating Index (BHEI).

\begin{tabular}{|c|c|c|c|c|c|c|c|}
\hline \multirow{2}{*}{ Components BHEI } & \multicolumn{7}{|c|}{ Score (points) } \\
\hline & 0 & & 5 & & 8 & 10 & 20 \\
\hline Total fruita & 0 & ---- & $1.0 \mathrm{po}$ & 000kcal & & & \\
\hline Whole fruitb & 0 & ---- & 0.5 po & 000kcal & & & \\
\hline Total vegetables & 0 & ---- & $1.0 \mathrm{po}$ & 000kcal & & & \\
\hline DG/OvegL & 0 & ---- & $0.5 \mathrm{po}$ & 000kcal & & & \\
\hline Total Cerealc & 0 & ---- & 2.0 por & $1000 \mathrm{kcal}$ & & & \\
\hline Whole Cereal & 0 & ---- & $1.0 \mathrm{po}$ & 000kcal & & & \\
\hline Milk and dairy productsd & 0 & ---- & - & ----- & & 1.5 portions/1000kca & \\
\hline Meat, eggs, and legumese & 0 & ---- & & ------ & & 1.0 portion $/ 1000 \mathrm{kca}$ & \\
\hline Oilsf & 0 & ---- & 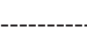 & ----- & & 0.5 portion $/ 1000 \mathrm{kcal}$ & \\
\hline Saturated fat & $\geq 15$ & ---- & ------- & 10 & --- & $\leq 7 \%$ of TEV & \\
\hline Sodium & $\geq 2.0$ & ---- & ------- & 1.0 & ---- & $\leq 0.75 \mathrm{~g} / 1000 \mathrm{kcal}$ & \\
\hline SoFAAs & $\geq 35$ & ---- & ---- & ------" & ------ & 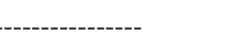 & $\leq 10 \%$ do TEV \\
\hline
\end{tabular}

Note: ${ }^{a}$ All fruit excluding fruit juice; ${ }^{b}$ All fruit including fruits and fruit juice; ${ }^{\mathrm{C}}$ Total grain: cereals, roots, and tubers; ${ }^{\mathbf{d}}$ Includes milk and other dairy products and soy-based beverages; '्ncludes legumes only after the meat, egg, and legume component reach the maximum score; fincludes monounsaturated and polyunsaturated fats, oils from oilseeds, and fat in fish.

DG/OvegL: Dark Green and Orange Vegetables and Legumes; SoFAAs: Energetic value from Solid Fat (saturated and trans fat), Alcohol, and Added Sugar; TEV: Total Energetic Value.

milliliters. Nutrient and energy calculations were performed using the Nutrition Data System for Research software (University of de Minnesota, Minneapolis, Minnesota, United States) [17]. The usual food and nutrient intake was estimated using the Multiple Source Method [18] to eliminate intra-personal variance intake.

The study variables were categorized to obtain descriptive and inferential statistics at $5 \%$ level of significance, and the measures of central tendency and dispersion were calculated. Regression analysis was carried out to evaluate the effect of the independent variables (sociodemographic, economic, and anthropometric characteristics, lifestyle, and health conditions) on the dependent variable Brazilian Healthy Eating Index. In the simple linear regression analysis (univariate regression), the independent variables with $p<0.20$ were selected for multiple regression analysis performing stepwise and forward selection. Statistically significant variables $(p<0.05)$ were maintained in the final model. Residual analysis of the final model showed homoscedasticity (constant variance), indicating that the data meet one of the assumptions which justify the use of linear regression. Data were statistically processed using Stata (Stata Corporation, College Station, Texas, United States) software version 12 .

The present study was approved by the Research Ethics Committee of the Universidade São Judas Tadeu (CAAE n 24855113.6.0 000.0089).

RES U L T S

The older adult population studied consisted mainly of female (85.1\%), married (44.7\%), and non-smoking (95.6\%) individuals with up to four years of schooling $(41.7 \%)$. The relationships between the BHEI score and the socio-demographic, economic, and lifestyle characteristics showed statistically significant differences between marital status, education level, and smoking habit. Widowed and smoking older adults had lower BHEl score than married and non-smoking older adults; older adults who had 9-12 or more years of schooling had higher BHEl score (Table 1). 
Table 1. Brazilian Healthy Eating Index according to the socio-demographic and lifestyle characteristics of older adults living in the municipality of São Caetano do Sul (SP), Brazil (2014).

\begin{tabular}{|c|c|c|c|c|c|c|c|c|}
\hline \multirow{2}{*}{ Variables } & \multicolumn{8}{|c|}{ Brazilian Healthy Eating Index } \\
\hline & $\mathrm{n}$ & $\%$ & Mean & \pm & SD & Minimum & Maximum & $p$ \\
\hline \multicolumn{9}{|l|}{ Gender } \\
\hline Female & 251 & 85.1 & 77.24 & \pm & 9.04 & 31.88 & 95.56 & \\
\hline Male & 44 & 14.9 & 78.85 & \pm & 8.16 & 58.11 & 91.04 & 0.269 \\
\hline \multicolumn{9}{|l|}{ Age (years) } \\
\hline 60 to 69 & 137 & 46.5 & 77.45 & \pm & 8.71 & 44.08 & 91.41 & \\
\hline 70 to 79 & 124 & 42.0 & 78.33 & \pm & 9.39 & 31.88 & 95.56 & 0.420 \\
\hline 80 or older & 34 & 11.5 & 74.43 & \pm & 7.39 & 55.65 & 87.47 & 0.077 \\
\hline \multicolumn{9}{|l|}{ Marital status } \\
\hline Married & 132 & 44.7 & 79.01 & \pm & 8.57 & 31.88 & 95.56 & \\
\hline Widowed & 107 & 36.3 & 75.85 & \pm & 9.43 & 43.22 & 91.41 & 0.006 \\
\hline Separated/divorced & 56 & 19.0 & 76.94 & \pm & 8.21 & 58.50 & 90.42 & 0.144 \\
\hline \multicolumn{9}{|l|}{ Lives alone } \\
\hline Yes & 75 & 25.4 & 78.13 & \pm & 8.43 & 55.65 & 91.41 & \\
\hline No & 220 & 74.6 & 77.25 & \pm & 9.08 & 31.88 & 95.56 & 0.461 \\
\hline \multicolumn{9}{|l|}{ Education level (years of schooling) } \\
\hline $0-4$ years & 123 & 41.7 & 75.90 & \pm & 8.49 & 43.22 & 91.75 & \\
\hline $5-8$ years & 62 & 21.0 & 75.86 & \pm & 10.75 & 31.88 & 91.41 & 0.972 \\
\hline $9-12$ years & 53 & 18.0 & 79.95 & \pm & 8.60 & 44.07 & 91.04 & 0.005 \\
\hline 12 years or more & 57 & 19.3 & 80.31 & \pm & 6.58 & 58.11 & 95.56 & 0.002 \\
\hline \multicolumn{9}{|l|}{ Employment status } \\
\hline Still works (including those that are retired) & 21 & 7.1 & 74.77 & \pm & 9.57 & 58.11 & 90.32 & \\
\hline Retired & 184 & 62.4 & 78.16 & \pm & 9.57 & 31.88 & 95.56 & 0.100 \\
\hline Homemaker & 86 & 29.2 & 76.73 & \pm & 9.20 & 43.22 & 90.39 & 0.220 \\
\hline \multicolumn{9}{|l|}{ Income $(M W)^{*}$} \\
\hline No income & 29 & 9.8 & 79.19 & \pm & 7.18 & 66.85 & 90.39 & \\
\hline Up to 1 & 62 & 21.0 & 75.06 & \pm & 10.57 & 31.88 & 91.75 & 0.039 \\
\hline$>1$ to $\leq 3$ & 130 & 44.0 & 77.19 & \pm & 9.10 & 43.22 & 91.41 & 0.274 \\
\hline$>3$ & 68 & 23.1 & 79.36 & \pm & 7.19 & 60.12 & 95.56 & 0.930 \\
\hline \multicolumn{9}{|l|}{ Physical activity } \\
\hline Yes & 256 & 86.8 & 77.36 & \pm & 9.10 & 31.88 & 91.75 & \\
\hline No & 39 & 13.2 & 78.19 & \pm & 7.69 & 58.11 & 95.56 & 0.588 \\
\hline \multicolumn{9}{|l|}{ Smoking habit } \\
\hline Yes & 13 & 4.4 & 70.49 & \pm & 11.65 & 44.07 & 87.54 & \\
\hline No & 282 & 95.6 & 77.79 & \pm & 8.66 & 31.88 & 95.56 & 0.004 \\
\hline
\end{tabular}

Note: "Minimum Wage in 2014=R\$724,00.

SD: Standard Deviation.

As for chronic non-communicable disease, there were no statistically significant differences $(p<0.05)$ between the BHEI score and the presence of hypertension (53.6\%), dyslipidemia, (42.0\%), and diabetes Mellitus (21.7\%) (Table 2).
With regard to health conditions, the older adults who had with their own natural teeth $(42.1 \%)$ and those who did not report having chewing problems (89.2\%) had higher the $\mathrm{BHEl}$ score. The association between nutritional status and BHEI score showed that obese older 
adults (30.8\%) had lower BHEI score (Table 2). However, the variables were not maintained in the multiple regression analysis (Table 3).

Investigating the relationship between the variables and the Brazilian Healthy Eating Index, it was observed that the widowed older adults and those who were separated or divorced, retired, and smokers had lower BHEI score, whereas those who had more years of schooling had higher mean scores (Table 3).

\section{I S C U S S I O N}

The present study analyzed the factors associated with diet quality of older adults living in the city of São Caetano do Sul, Brazil. The main findings showed that those with higher education level (9 to 12 or more years of schooling) had higher diet quality, and those who were widowed or separated, retired, and smokers.

There was no significant difference between diet quality and gender, corroborating

Table 2. Brazilian Healthy Eating Index mean scores according to the health conditions of older adults living in the municipality of São Caetano do Sul (SP), Brazil (2014).

\begin{tabular}{|c|c|c|c|c|c|c|c|c|}
\hline \multirow{2}{*}{ Variables } & \multicolumn{8}{|c|}{ Brazilian Healthy Eating Index } \\
\hline & $\mathrm{n}$ & $\%$ & Mean & \pm & SD & Minimum & Maximum & $p$ \\
\hline \multicolumn{9}{|c|}{ Have own natural teeth } \\
\hline Yes & 124 & 42.1 & 79.03 & \pm & 8.12 & 43.22 & 95.56 & \\
\hline No & 171 & 57.9 & 76.34 & \pm & 9.31 & 31.88 & 91.75 & 0.001 \\
\hline \multicolumn{9}{|c|}{ Chewing problems } \\
\hline Yes & 32 & 10.8 & 74.52 & \pm & 9.98 & 51.90 & 90.00 & \\
\hline No & 263 & 89.2 & 77.83 & \pm & 8.73 & 31.88 & 95.56 & 0.047 \\
\hline \multicolumn{9}{|c|}{ Choking or gagging when swallowing } \\
\hline Yes & 7 & 2.4 & 76.25 & \pm & 7.30 & 63.66 & 86.25 & 0.714 \\
\hline No & 288 & 97.6 & 77.50 & \pm & 8.96 & 31.88 & 95.56 & \\
\hline \multicolumn{9}{|l|}{ Abdominal pain } \\
\hline Yes & 16 & 5.4 & 74.01 & \pm & 8.94 & 55.22 & 85.20 & 0.111 \\
\hline No & 279 & 94.6 & 77.67 & \pm & 8.89 & 31.88 & 95.56 & \\
\hline \multicolumn{9}{|l|}{ Use of laxatives } \\
\hline Yes & 11 & 3.7 & 74.79 & \pm & 10.24 & 57.39 & 88.74 & 0.310 \\
\hline No & 284 & 96.3 & 77.58 & \pm & 8.86 & 31.88 & 95.56 & \\
\hline \multicolumn{9}{|l|}{ Hypertension } \\
\hline Yes & 164 & 55.6 & 77.75 & \pm & 7.90 & 51.90 & 91.75 & 0.545 \\
\hline No & 131 & 44.4 & 77.12 & \pm & 10.06 & 31.88 & 95.56 & \\
\hline \multicolumn{9}{|l|}{ Dyslipidemia } \\
\hline Yes & 124 & 42.0 & 77.41 & \pm & 8.86 & 43.22 & 95.56 & 0.914 \\
\hline No & 171 & 58.0 & 77.52 & \pm & 8.98 & 31.88 & 91.75 & \\
\hline \multicolumn{9}{|l|}{ Diabetes Mellitus } \\
\hline Yes & 64 & 21.7 & 77.41 & \pm & 8.86 & 43.22 & 95.56 & 0.914 \\
\hline No & 231 & 78.3 & 77.52 & \pm & 8.98 & 31.88 & 91.75 & \\
\hline \multicolumn{9}{|l|}{ Nutritional status } \\
\hline Eutrophic & 125 & 42.4 & 78.44 & \pm & 7.65 & 57.39 & 95.56 & \\
\hline Undernourished & 41 & 13.9 & 76.83 & \pm & 9.41 & 43.22 & 91.34 & 0.316 \\
\hline Overweight & 38 & 12.9 & 78.56 & \pm & 7.45 & 58.98 & 90.86 & 0.942 \\
\hline Obese & 91 & 30.8 & 75.98 & \pm & 10.61 & 31.88 & 91.75 & 0.046 \\
\hline
\end{tabular}

Note: SD: Standard Deviation. 
the findings of another study on older adults in different cities and states in Brazil [7,8]. However, some studies with adults and older adults have reported higher BHEI score for women $[9,10]$. Assumpção et al. [10] found that women consumed more vegetables, fruits, and milk and less sodium, meat, saturated fat, alcohol, and added sugar, when compared to men. The diet quality similarity found between female and male individuals living in São Caetano do Sul can be explained by the fact that most of the older adults studied were married and retired,

Table 3. Association between Brazilian Healthy Eating Index scores and characteristics of older adults living in the municipality of São Caetano do Sul (SP), Brazil (2014).

\begin{tabular}{|c|c|c|c|c|}
\hline \multirow{2}{*}{ Characteristics } & \multicolumn{2}{|c|}{ Univariate regression } & \multicolumn{2}{|c|}{ Multivariate regression } \\
\hline & $\beta$ & $p$ & $\beta$ & $p$ \\
\hline \multicolumn{5}{|l|}{ Gender } \\
\hline Female & 1.00 & & & \\
\hline Male & 1.62 & 0.269 & - & \\
\hline \multicolumn{5}{|l|}{ Age (years) } \\
\hline 60 to 69 & 1.00 & & & \\
\hline 70 to 79 & 0.89 & 0.420 & - & \\
\hline 80 or older & -3.01 & 0.077 & & \\
\hline \multicolumn{5}{|l|}{ Marital status } \\
\hline Married & 1.00 & & & \\
\hline Widowed or separated & -2.79 & 0.007 & -2.02 & 0.047 \\
\hline \multicolumn{5}{|l|}{ Lives alone } \\
\hline Yes & 1.00 & & & \\
\hline No & -0.88 & 0.461 & - & \\
\hline \multicolumn{5}{|c|}{ Education level (years of schooling) } \\
\hline $0-4$ years & 1.00 & & & \\
\hline $5-8$ years & -0.05 & 0.972 & -0.58 & 0.965 \\
\hline $9-12$ years & 4.04 & 0.005 & 3.49 & 0.013 \\
\hline 12 years or more & 4.41 & 0.002 & 3.92 & 0.005 \\
\hline \multicolumn{5}{|l|}{ Employment status } \\
\hline Still works & 1.00 & & & \\
\hline Retired & -3.39 & 0.100 & -4.24 & 0.034 \\
\hline Homemaker & -1.43 & 0.220 & -0.14 & 0.903 \\
\hline \multicolumn{5}{|l|}{ Income (MW) } \\
\hline No income & 1.00 & & & \\
\hline Up to 1 & -4.13 & 0.039 & - & \\
\hline$>1$ to $\leq 3$ & -2.00 & 0.274 & & \\
\hline$>3$ & 0.17 & 0.930 & & \\
\hline \multicolumn{5}{|l|}{ Smoking habit } \\
\hline Yes & -7.31 & 0.004 & -8.06 & 0.001 \\
\hline No & 1.00 & & & \\
\hline \multicolumn{5}{|l|}{ Nutritional status } \\
\hline Eutrophic & 1.00 & & & \\
\hline Undernourished & -1.61 & 0.316 & - & \\
\hline Overweight & 0.12 & 0.942 & & \\
\hline Obese & -2.45 & 0.046 & & \\
\hline
\end{tabular}

Note: MV: Minimum Wage. 
and thus they probably had meals together with their spouses. Moreover, widowed older adults had lower BHEl score than married individuals; there are no studies available addressing the association between diet quality and marital status. However, Borim et al. [19] found that older adults who lived alone had higher diet quality.

The relationship between BHEI score and education level showed higher scores among the older adults with 9 or more years of schooling. A similar result was found by Morimoto et al. [11], who justified that individuals with higher education level may have higher income and better knowledge about food. Assumpção et al. [10] observed that individuals with higher education level had higher BHEl score for the components whole grains, fruits, vegetables, and milk and other dairy products.

The practice of leisure time physical activity provides health benefits to older adults. Studying older adults, Xu et al. [12] found an association between diet quality and faster gait speed. Assumpção et al. [8] reported that older adults participating in physical activities had higher BHEI score. However, no difference was observed between the practice of physical activity and BHEI score in the present study.

Smoking individuals had lower BHEI score, similar to the findings reported in other studies $[7,12,20,21]$. Although not very frequent in the studied population, this habit significantly affected diet quality, and several studies $[12,21]$ have reported an association between lower intake of foods such as fruits, vegetables, and dairy products among smokers.

In the present study, it was also found that older adults with dental prosthesis who reported chewing problems had lower BHEI score. Corroborating findings of the present study, other studies found lower BHEI score [22] in edentulous older adults [13] and in those with oral cavity problems [22] and reported that oral health is a major factor affecting diet quality [23] of older adults.
Among the main morbidities among older adults reported in the literature, hypertension was the most frequent, but it was not associated with diet quality. Unlike the present study, Assumpção et al. [8] and Chen et al. [24] found that older adults with diabetes had higher BHEI score, and these authors stated that patients with chronic diseases can make healthier food choices since they are frequently given nutritional guidance and recommendations, hoping that after being diagnosed, patients are encouraged to adopt a healthier lifestyle [25].

Despite the high number of eutrophic older adults, approximately $1 / 3$ of the studied population was classified as obese. These results confirm the current situation since according to the Family Budget Survey 2008/2009 data, there is high prevalence of overweight older adults in Brazil [26]. In the present study, it was found that eutrophic older adults had higher BHEI score than obese older adults, similar to the results found by Oliveira et al. [27].

The present study showed some limitations such as the use of a non-probability sample since it hinders comparison between national and international population studies. However, to reduce this bias, the participants were selected among the fifteen neighborhoods geographically distributed in the city, which have different social, demographic, and economic characteristics. Another possible limitation is the participants' age because age-related changes such as trouble concentrating and memory problems can increase the length of the interviews requiring more attention by the interviewers. Accordingly, the training of the nutritionists involved in the research and the space available for data collection were fundamental to ensure the reliability of the information collected, analysis, and results obtained.

Finally, it is worth mentioning that the instrument used to evaluate diet quality considers both the consumption and the probability of consumption of several food items, data obtained using a food frequency questionnaire and two $24 \mathrm{HR}$ interviews, allowing the evaluation of the 
usual diet. The BHEl is a tool that can be used in future interventions among older adults and to compare results obtained in studies using similar instruments.

\section{CONCLUSION}

The findings of this study provide information on the diet quality of older adults identifying differences according to sociodemographic, economic, and anthropometric characteristics and lifestyle and health conditions. Diet quality was better in individuals with higher education level and worse lower in those who were widowed or separated, retired, and smokers, indicating that these factors can influence food choices. These results show the need for improvements in the diet quality and quality of life of this population, mainly through the provision of better nutritional care and more comprehensive health care services, as well as the adoption of strategies for promoting their health. Further studies on diet quality are recommended in order to develop public policies focused on diet and nutrition of older adults.

\section{CONTRIBUTORS}

TI FREITAS raised the data, reviewed the literature, analyzed and interpreted the results and wrote the article. AN PREVIDELLI performed the statistical analysis and interpreted the results. MPN FERREIRA and KM MARQUES raised the field data and interpreted the results. RMM GOULART collaborated in the study and interpreted the results. RC AQUINO designed and coordinated the study and conducted the final critical revision of the manuscript.

\section{REFERENCES}

1. Instituto Brasileiro de Geografia e Estatística. Projeção populacional do Brasil: comunicação social. Brasília: IBGE; 2013.

2. Programa das Nações Unidas para o Desenvolvimento. Brasil ocupa $73^{a}$ posição entre 169 países no IDH. Brasília: IBGE; 2010.
3. Soenen S, Chapman IM. Body weight, anorexia, and undernutrition in older people. J Am Med Dir Assoc. 2013;14(Suppl.9):642-8. https://doi. org/10.1016/j.jamda.2013.02.004

4. Fisberg RM, Marchioni DML, Castro MA, Verly Junior E, Araújo MC, Bezerra IN, et al. Ingestão inadequada de nutrientes na população de idosos do Brasil: Inquérito Nacional de Alimentação 2008-2009. Rev Saúde Pública. 2013;47(Suppl.1):2225-305. https://doi. org/10.1590/\$0034-89102013000700008

5. Mendes A, Gavioli L, Previdelli AN, Fisberg RM, Marchioni DML. The diet quality index evaluates the adequacy of energy provided by dietary macronutrients. Rev Nutr. 2015;28(Suppl.4):341-8. https://doi.org/10.1590/1415-527320150004 00001

6. Previdelli AN, Andrade SC, Pires MM, Ferreira SMG, Fisberg RM, Marchioni DM. Índice de qualidade da dieta revisado para população brasileira. Rev Saúde Pública. 2011;45(Supl.4):794-8. https://doi. org/10.1590/S0034-89102011005000035

7. Closs VE. Associação do estado nutricional e do índice de alimentação saudável com síndrome metabólica em idosos [dissertação]. Rio Grande do Sul: Pontifícia Universidade Católica do Rio Grande do Sul; 2011.

8. Assumpção D, Domene SMA, Fisberg RM, Barros MBA. Qualidade da dieta e fatores associados entre idosos: estudo de base populacional em Campinas, São Paulo, Brasil. Cad Saúde Pública. 2014;30(Supl.8):1680-94. https://doi.org/10. 1590/0102-311X00009113

9. Loureiro AS, Silva RMVG, Rodrigues PR, Pereira RA, Wendpap LL, Ferreira MG. Diet quality in a sample of adults from Cuiabá (MT), Brazil: Association with sociodemographic factors. Rev Nutr. 2013;26(Suppl.4):431-41. https://doi. org/10.1590/S1415-52732013000400005

10. Assumpção D, Domene SMA, Fisberg RM, Barros MBA. Social and demographic inequalities in diet quality in a population-based study. Rev Nutr. 2016;29(Supl.2):151-62. https://doi.org/10.1590/16 78-98652016000200001

11. Morimoto JM, Latorre MRDO, César CLG, Carandina $L$, Barros MBA, Goldbaum $M$, et al. Fatores associados à qualidade da dieta de adultos residentes na Região Metropolitana de São Paulo, Brasil, 2002. Cad Saúde Pública. 2008;24(Suppl.1):169-78. https://doi.org/10.15 90/ S0102-311X2008000100017

12. Xu B, Houston DK, Locher JL, Ellison KJ, Gropper S, Buys DR, et al. Higher Healthy Eating Index-2005 scores are associated with better physical 
performance. J Gerontol A Biol Sci Med Sci. 2012;67(Suppl.1):93-9. https://doi.org/10.1093/ gerona/glr159

13. Zhu Y, Hollins JH. Tooth loss and its association with dietary intake and diet quality in American adults. J Dentistry 2014;42(Suppl.11):1428-35. https://doi.org/10.1016/j.dent.2014.08.012

14. Hair JF, Black WC, Babin BJ, Anderson RE, Tatham RL. Análise multivariada de dados. $5^{a}$ ed. Porto Alegre: Bookman; 2005.

15. Organización PanAmericana de la Salud. Encuestra multicêntrica: Salud Bienestar y Envejecimento (SABE) em America Latina e el Caribe: Informe Preliminar. In: Anales 36 Reunión del Comitê Asesor de Investigaciones en Salud; 2001.

16. Marchioni DML, Fisberg RM. Manual de avaliação do consumo alimentar em estudos populacionais: a experiência do inquérito de saúde em São Paulo (ISA). São Paulo: USP; 2012

17. Nutrition Data System for Research. Version 2013. University of Minnesota: USDA; 2013.

18. Harttig U, Haubrock J, Knüppel S, Boeing $H$. The MSM program: The web-based statistics package for estimating usual dietary intake using the Multiple Source Method, 2011. Eur J Clin Nutr. 2011;65(Suppl.1):87-91. https://doi.org/10.1038/ ejcn.2011.92

19. Borim FSA, Barros MBA, Neri AL. Autoavaliação da saúde em idosos: pesquisa de base populacional no Município de Campinas, São Paulo, Brasil. Cad Saúde Pública. 2012;28(Supl.4):769-80. https:// doi.org/10.1590/S0102-311X2012000400016

20. Previdelli AN, Lipi M, Castro MA, Marchioni DML. Dietaryqualityandassociatedfactorsamongfactory workers in the metropolitan region of São Paulo, Brazil. J Am Diet Assoc. 2010;110(Suppl.5):786-90. https://doi.org/10.1016/j.jada.2010.02.002

21. McClernon FJ, Westman EC, Rose JE, Luiz AM. The effects of foods, beverages, and other factors on cigarette palatability. Nocotine Tob Res. 2007;9(Suppl.4):355-63. https://doi.org/10.10 80/14622200701243177

22. Savoca MR, Arcury TA, Leng $X$, Chen $H$, Bell RA, Anderson AM, et al. Severas Tooth Loss in older Adults as a Key indicador of compromised Diet Quality, 2010. Public Health Nutr. 2010;13(Suppl.4):466-74. https://doi.org/10.1017/ S13 68980009991236

23. Tramontino VS, Nuñes JMC, Takahashi JMFK, Daroz CBS, Barbosa CMR. Nutrição para idosos. Rev Odontol Univ Cid São Paulo. 2009;21(Supl.3):258-67.

24. Chen X, Cheskin LJ, Shi L, Wang Y. Americans with diet-related chronic diseases report higher diet quality than those without these diseases. J Nutr. 2011;141(Suppl.8):1543-51. https://doi. org/10.3945/jn.111.140038

25. Lima LA, Nedel FB, Olinto MTA, Baldisserotto J. Hábitos alimentares de hipertensos e diabéticos atendidos em um serviço de Atenção Primária à Saúde do Sul do Brasil. Rev Nutr. 2015;28(Supl.2):197-206. https://doi.org/10.15 90/1415-52732015000200 008

26. Instituto Brasileiro de Geografia e Estatística. Pesquisa de orçamento familiar 2008-2009: antropometria e estado nutricional de crianças, adolescentes e adultos no Brasil. Rio de Janeiro: IBGE; 2010.

27. Oliveira ML, Calahani LM, Previdelli AN, Malta MB, Corrente JE, Papini SJ. Aplicação do Índice de Qualidade da Dieta Revisado antes e após orientação nutricional. Rev Ciênc Med. 2015;24(Supl.1):29-36. https://doi.org/10.1590/ S0102-311X2008000100017

Received: April 13, 2016

Final version: December 15, 2016 Approved: January 31, 2017 